\title{
UNIVERSITYOF
}

FORWARD

THINKING

WESTMINSTER用

WestminsterResearch

http://www.westminster.ac.uk/westminsterresearch

\section{Productivity growth and convergence: a stochastic frontier analysis}

Moura e Sa Cardoso, C. and Ravishankar, G.

This article is ( ) Emerald and permission has been granted for this version to appear here http://westminsterresearch.wmin.ac.uk/18333/

Emerald does not grant permission for this article to be further copied/distributed or hosted elsewhere without the express permission from Emerald Group Publishing Limited.

The final, published version in the Journal of Economic Studies, 42 (2), pp. 224-236, 2015 is available at:

https://dx.doi.org/10.1108/JES-08-2013-0121

The WestminsterResearch online digital archive at the University of Westminster aims to make the research output of the University available to a wider audience. Copyright and Moral Rights remain with the authors and/or copyright owners.

Whilst further distribution of specific materials from within this archive is forbidden, you may freely distribute the URL of WestminsterResearch: ((http://westminsterresearch.wmin.ac.uk/)).

In case of abuse or copyright appearing without permission e-mail repository@westminster.ac.uk 


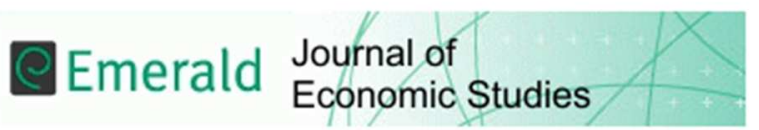

\section{Productivity growth and convergence: a stochastic frontier analysis}

\begin{tabular}{|r|l|}
\hline Journal: & Journal of Economic Studies \\
\hline Manuscript ID: & JES-08-2013-0121.R2 \\
\hline Manuscript Type: & Research Paper \\
\hline Keywords: & Regional growth, SFA, Human Capital \\
\hline \multicolumn{3}{c}{} \\
\\
\multicolumn{3}{c}{$\begin{array}{r}\text { SCHOLARONE } \\
\text { Manuscripts }\end{array}$} \\
\end{tabular}




\section{Productivity growth and convergence: a stochastic frontier analysis}

\section{Introduction}

Educational levels in Spain have seen considerable improvement in the last four decades. This improvement over time was particularly striking post 1990 when there was a greater reduction in the gap of average educational levels in Spain vis-à-vis that of the OECD. Spain is known to have significant regional disparities (Doran and Jordan, 2013) and the availability of a rich regional dataset on physical and human capital has facilitated considerable research on this area (de la Fuente, 2002). In particular, the role of human capital in Spain's regional productivity growth has received considerable attention (de la Fuente, 2002; López-Bazo and Moreno, 2007).

The received literature on regional growth draws on endogenous growth theory to examine the impact of human capital on economic growth (for example: Ang et al., 2011). The positive association between human capital development and economic growth is theorized to occur via external scale economies associated with human capital and the complementarity between human and physical capital (Sanromá and Ramos, 2007).

However, this literature inherently assumes a production process that efficiently combines human capital and other inputs to produce the maximum feasible output level. In other words, output levels are placed on the production frontier and inefficient production is assumed away so that observed regional output levels are coincident with the maximum (technically efficient) output levels. Estimations of growth that fail to take into account productive inefficiencies may thus generate biased parameters. The 
importance of accounting for the possibility of inefficient production is illustrated by the findings of Bos et al. (2010) and Albert (2000). The latter specifically studies regional growth in Spain utilizing the Stochastic Frontier Analysis (SFA) approach, but with an important drawback which is the absence of human capital in the estimations of regional growth. Moreover, the regional level of the data is NUTS ${ }^{1}{ }^{1}$.

By departing from the assumption of efficient production, we make the following contributions. First, in contrast to the traditional approaches of regional growth which estimate average production functions, we adopt the Stochastic Frontier Analysis in which regional production can deviate from the maximum possible due to both technically inefficient production and random disturbances. This approach enables the assessment of the degree to which a given region's observed output deviates from the maximal possible. In doing so, the resulting region specific productive efficiencies are modeled as outcomes of the level of human capital. As noted by Manca (2012), regional growth is intimately linked with the relative efficiency that economic agents adopt and implement available technology. Consequently, variations in levels of human capital development impact regional economic growth in a complex manner.

Secondly, with greater development of human capital and the externalities associated, the levels of inefficiency are theorized to decline. To evaluate this, regional efficiencies are utilised to determine the convergence levels thereby providing an understanding of the efficiency growth at the regional level. The application of this methodology leads to new findings on regional efficiency

\footnotetext{
${ }^{1}$ NUTS stands for the European Commission's Nomenclature of Units of Territorial Statistics. The highest level of regional disaggregation is NUTS III.
} 
growth in Spain and has direct consequences in informing policies designed to enhance regional development.

Finally, all estimations are deployed on a dataset that identifies the regions and their respective inputs and outputs at a NUTS III level of disaggregation. This affords a richer level of data detail within which to assess the effect of human capital on regional productivity growth.

To-date there are very few studies that examine Spanish regional efficiency and even fewer that do so at the NUTS III level of disaggregation which corresponds to the Spanish provinces. One of the closest studies is that of Badunenco and Romero-Ávila (2012) however, the authors use a NUTS II level dataset and adopt the deterministic Data Envelopment Analysis approach to study regional productivity growth and convergence in Spain over the period $1980-2003$.

This paper estimates the efficiency scores (EFFS) for the Spanish NUTS III regions for the period 1991-2006, and links these scores with the human capital level by applying a stochastic frontier approach. Furthermore, this allows estimation of the $\beta$-convergence equation for the regional efficiency levels in order to assess the degree to which regions identified as relatively inefficient converge to the best practice.

\section{Literature Review}

The role of human capital in the Spanish regional growth has been studied by several authors, yet most of them apply the NUTS II level of regional disaggregation and use different approaches. Their specifications vary while the most common are either a convergence equation (Barro and Sala-i-Martin, 
1992) or an aggregated production function. In the former, the regional growth rate is explained by a set of explanatory variables including the initial income per capita or per worker and human capital levels.

For example, de la Fuente (2002) concluded that the equalization of education levels contributed to the reduction of productivity disparities over the period 1955-1991 by estimating a convergence equation. Di Liberto (2007) studied the role of human capital in regional growth over the period 1964-1997 by estimating the convergence equation and dividing the regions into two clubs by their level of GDP per capita and human capital. The average years of total education and the average years of secondary schooling played a positive and significant role only in the rich regions, in contrast with the significant and positive effect of primary schooling in the poor club. For a shorter period, 1995-2000, Galindo-Martín and Álvarez-Herranz (2004) proxied human capital by a labour-income measure and by estimating the production function found a positive effect on regional GDP per capita growth. López-Bazo and Moreno (2007) estimated both the private and social returns to human capital for the period $1980-1995$ by using a cost-system in which human capital is included as a factor that shifts the cost function. Higher human capital externalities were found in the regions which were initially in a worse position. The same authors (López-Bazo and Moreno, 2008) distinguished the direct effect of human capital on output from its indirect effect of stimulating investment in physical capital. Their findings suggest not only a positive effect of human capital on aggregate productivity but also a significant indirect effect through the stimulation of investment in physical capital. Only Ramos et al. (2010) focused on the human capital effects at the 
NUTS III level of regional disaggregation and estimated both the production function and the convergence equations by using spatial econometrics. Despite a positive impact of education on productivity growth, no evidence of human capital regional spillovers was found.

\section{Methodology}

A production unit is considered technically efficient if, using the given technology, it produces the maximum output using a given level of inputs. Developed independently by Aigner et al. (1977) and Meeusen and Van Den Broeck (1977), Stochastic Frontier Analysis (SFA) specifies a production frontier wherein the error term is comprised of producer specific inefficiency and random error. Thus, the production function for a panel of $N$ regions in $T$ time periods using a vector of $x$ inputs, such that $x \in R_{+}^{m}$, to produce the output vector $y$ is specified as follows:

$$
\begin{aligned}
& Y_{n t}=\beta_{0}+x_{n t}^{\prime} \beta+\varepsilon_{n t} \\
& \varepsilon_{n t}=v_{n t}-u_{n t}
\end{aligned}
$$

where $y_{n t}$ is the $n^{\text {th }}$ region's output in log values in the $t^{\text {th }}$ period, $x_{n t}$ is the logged value of the inputs and $\beta$ is a vector of unknown parameters to be estimated. Technical inefficiency resides in the composed error term $\varepsilon_{n t}$, which is thus specified as $\left(v_{n t}-u_{n t}\right)$. The $v_{n t}$ represents random error that is i.i.d normally distributed and $u_{n t}$ is a non-negative random variable representing technical inefficiency.

Studies that use the stochastic frontier analysis framework to estimate macroeconomic production functions include those of Mastromarco and 
Ghosh (2008) and Afonso and St. Aubyn (2010). The former examine the link between technology diffusion and total factor productivity (TFP) with levels of human capital playing a crucial role in enhancing TFP. Afonso and St. Aubyn (2010) confirm the relevance of human capital development for growth in their study of OECD countries. Sanroma and Ramos (2007) using Spanish regional data at a NUTS III level also find a positive relationship between human capital stocks and regional productivity. However this study does not use a frontier approach.

To assess regional productivity, the Cobb-Douglas stochastic production frontier is estimated in its intensive form as follows:

$$
\left(\frac{G D P}{L A B O U R}\right)_{i}^{t}=\theta_{0}+\theta_{1}\left(\frac{C A P I T A L}{L A B O U R}\right)_{i}^{t}+\theta_{2} T I M E+v_{i}^{t}-u_{i}^{t}
$$

In which the output per worker of region $i$ in period $t$ is measured via $\left(\frac{G D P}{L A B O U R}\right)_{i}^{t}$ depends on the physical capital to labour ratio, $\left(\frac{C A P I T A L}{L A B O U R}\right)_{i}^{t}$, the capital per worker. The variables are specified in natural log (In) values. Additionally, we specify a time trend variable, TIME to account for neutral technical change.

To operationalise (3), we adopt the Battese and Coelli (1995) SFA model wherein the inefficiency effects are obtained as truncations of a normal distribution with a constant variance but with means that are a function of observable linear variables ${ }^{2}$. Thus, $v_{n t} \sim N\left(0, \sigma_{\varepsilon}^{2}\right)$ while $u_{n t}$ is obtained by the truncation at zero of a normal distribution with mean $z_{i t \delta}$ and variance $\sigma^{2}$.

\footnotetext{
${ }^{2}$ A comprehensive review of SFA models is provided in Coelli et al. (1998) and Kumbhakar and Lovell (2000).
} 
$z_{i t}$ is a vector of observed variables that influence inefficiency and $\delta$ is a vector of unknown parameters to be estimated. In this case, these z-vectors comprise measures of human capital, which thus form the primary determinants of inefficiency. As such, observed regional efficiency levels are attributed to the levels of human capital development. Specifically, regional inefficiency is modelled directly as a function of the following explanatory variables:

$$
\begin{aligned}
u_{i}^{t}= & \theta_{0}+\theta_{1} \text { PRIMARY }{ }_{i}^{t}+\theta_{2} \text { SECONDARY }{ }_{i}^{t}+\theta_{3} \text { TERTIARY } \\
& +\theta_{3} \text { AGRI }+\theta_{4} \text { TIME }+v_{i}^{t}-u_{i}^{t}
\end{aligned}
$$

The received literature suggests that higher human capital levels are associated with higher growth (Mankiw et al, 1992; Lucas, 1988; Romer, 1990; Hansen and Knowles, 1998). More recently, Petrakis and Stamatakis (2002) show that primary and secondary education play a greater role in fostering growth among less developed countries while higher education is more relevant in developed countries. Of direct relevance to this paper, is $\mathrm{Di}$ Liberto's (2007) evidence of the positive effects of human capital development in fostering Spanish regional growth. Using regional data at a NUTS II level, the author further finds that primary education is particularly significant in bolstering growth among poor regions while secondary schooling takes on a

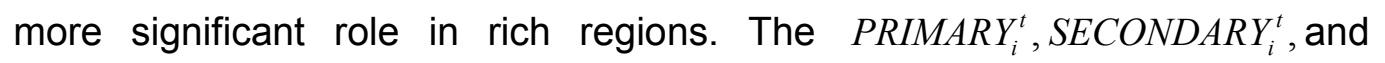
TERTIARY ${ }_{i}^{t}$ variables in (4) thus allow for the case wherein the technical efficiency of different regions are varyingly impacted by differing education levels thereby impacting the ability of the region to maximise GDP per worker. 
As such, negative and significant educational parameter values are associated with lower levels of regional inefficiency.

$A G R I_{i}^{t}$, the share of agricultural sector in total gross value added (GVA) records the level of development of the region. The higher this share, the less developed and further from the best practices the region is. Therefore, a high weight of agriculture is expected to increase the inefficiency level.

Finally, to assess time variation in regional efficiency, a time trend variable, TIME, is included in (4), which when negative and significant evidences an increase in regional efficiency over time.

The parameters in (3) and (4) are jointly obtained via the Maximum Likelihood Estimation method, following which region specific Technical Efficiency $(T E)$ at the $t^{\text {th }}$ period is obtained using Battese and Coelli (1995):

$$
T E_{i t}=E\left[\exp \left(-U_{i t}\right) \varepsilon_{i t}\right]
$$

These region specific efficiency scores measure the distance of the $i^{\text {th }}$ region's observed output levels in time period $t$ to its frontier level of output. An efficiency value of unity would thus indicate that the region was on its frontier and utilising available technology to produce the maximum possible output level. An efficiency score lower than 1 indicates that the region had scope to further increase its output given its observed inputs.

The analysis proceeds by testing absolute convergence of the efficiency scores. The concept of $\beta$-convergence was proposed by Barro and Sala-iMartin (1992) and it is defined as an inverse relationship between the growth rate and the initial level of income per capita. In the regional context, this means that poorer regions grow faster, which is explained by the diminishing 
returns of the physical capital accumulation. Never the less, the concept can be applied to a variety of economic variables. In this case $\beta$-convergence tests if the efficiency level grows faster in the less efficient regions than in the most efficient ones suggesting catching-up. Following Weill (2009) and Mamatzakis et al. (2008), we estimate the $\beta$-convergence equation using the efficiency scores previously obtained:

$$
\ln E f f_{i, t}-\ln E f f_{i, t-1}=\alpha+\beta \ln E f f_{i, t-1}+\varepsilon_{i, t}
$$

where $\ln E f f_{i, t}$ is the logged efficiency score of the $i^{\text {th }}$ region in the $t^{\text {th }}$ time period and $\ln \mathrm{Eff}_{\mathrm{i}, \mathrm{t}-1}$ is the logged efficiency score of the $i^{\text {th }}$ region in the previous period. A significant and negative $\beta$-coefficient indicates convergence in the sense that the most inefficient regions initially are those that exhibit a higher growth rate in the respective efficiency score. In other words, the regions are converging faster. This equation is estimated through the system-GMM, which controls for endogeneity.

\section{Data}

The panel includes 50 Spanish NUTS III regions (provinces) between 1991 and 2006. Data on GDP per worker was collected from the Spanish National Institute of Statistics' (INE) Regional Accounts. Before 1995, the GDP nominal values are provided in the country's national currency, Pesetas, and according to the 1986 accounting system. The nominal regional GDP for 1994 is given for both accounting systems (1986 and 1995), so this common year was used to convert the previous years (1991-93) values into a series closer to the 1995 new accounting system. The second step was to convert the GDP value into Euros by using the respective exchange rate at 31 December 1998 
$(€ 1=166.66$ Pesetas). GDP real values were then calculated using the GDP deflator and 2000 was the base year.

Data on physical and human capital at the NUTS III level of regional disaggregation are available from the Fundación BBVA (Banco BilbaoViscaya)-IVIE (Instituto Valenciano de Investigaciones Económicas) for the gross physical capital stock and the Fundación Bancaja-IVIE for the regional human capital stock. According to de la Fuente (2002), these regional datasets are unique and have important advantages, namely the fact that the data are fully comparable across regions and over time.

The physical capital stock series integrates all the public and private sector capital stocks, including the residential capital. According to the data source it was computed by using the perpetual inventory method and following the OECD recommendations. In what concerns the human capital series, the main source of the data are the labour force surveys. For each NUTS III region, the IVIE human capital dataset provides data on the average years of education for the total labour force, the employed and also the unemployed workers. We chose to use the average years of education of the employed workers since it fits better the purpose of our study. This average years of schooling is decomposed into different levels (Primary, Secondary and Tertiary Education).

Table 1 provides the descriptive statistics for selected regions as well as the national average at the beginning of the period. The richest regions in terms of GDP per worker tend also to be the richest in human capital, which are Madrid and those located in País Vasco (Basque Country) and Cataluña. On the other hand, the poorest regions are located in Extremadura, Andalucía 
and Galicia and tend to remain poor over the period. The main differences between the two extreme groups lay in the human capital gap and the share of agriculture in total GVA. The GDP per worker average annual growth rate is clearly higher in the group of the poorest regions suggesting a catching-up mechanism. In most of the richest regions the average annual growth rate is negative which indicates a productivity decline over the period. Furthermore, among the richest regions, only in Vizcaya and Guipúzcoa the GDP per worker growth rate is higher than the national average.

\section{[Insert Table 1]}

\section{Results}

Region specific inefficiency is modelled as a function of the average levels of primary, secondary and tertiary education. Additional variable used is the share of agricultural sector in the total gross value added (GVA) in order to control for the level of regional development. This variable is expected to have a positive effect in the regional specific inefficiency level since the total factor productivity tends to be lower in this sector.

The requisite SFA model, as detailed in equation (2), is run in conjunction with these variables along three model specifications. In Model 1, capital and labour is used to determine the GDP per worker and a time trend is incorporated to capture movement of the frontier over time. The inefficiency terms are determined by the average years of primary, secondary and tertiary education with the share of the agricultural sector as a control variable. This forms our baseline model. Model 2, additionally, incorporates the time trend 
variable as a determinant of inefficiency, thereby providing an indication of the temporal evolution on inefficiency. A negative and significant time trend variable would thus indicate a fall in inefficiency over time. Finally, Model 3, includes an interaction between the capital and time trend.

Maximum likelihood estimates of the model parameters are provided in Table 2. As can be seen, all variables have the expected signs. The physical capital per worker has a significant positive effect on the productivity level across all the models. The time trend variable, however, is not found to be significant.

\section{[Insert Table 2]}

Turning to the human capital proxies, upon which regional inefficiencies are contingent, Table 2 shows that increasing levels of human capital development is associated with lower regional inefficiency. This is evidenced by the significant and negatively signed coefficient values for the average levels of primary, secondary and tertiary education. All the levels of education contributed to reduce the inefficiency levels, however secondary schooling played a stronger role than primary and even higher education. The share of agriculture in total gross value added was introduced as a proxy for the level of development of the region. As expected, the less developed is a region the higher the inefficiency. An examination of the region specific inefficiencies would serve to assess the degree to which the above factors impact the productive capabilities of the regions. Table 3, thus, reports the regional efficiency scores. 


\section{[Insert Table 3]}

As expected, the most efficient regions are simultaneously the richest in terms of GDP per worker and are those in the Basque country (Álava, Guipúzcoa, Vizcaya), Navarra and Comunidad de Madrid. Figures 1 and 2 illustrate the spatial distribution of the efficiency scores (obtained according to model 1) across the Spanish provinces. The darkest regions represent the most efficient in the beginning and at the end of the period. Apart from the capital region, Madrid, which is among the most efficient regions as expected, the other regions are Navarra and those located at Basque Country, which are all in the Northeast. The less efficient are located in Extremadura. While, there is a tendency for persistency in levels of inefficiency over the period, there are a few cases of regional mobility such as the decline of the islands (Canary and Balears) and the provinces that integrate Andalucía (Granada, Almeria, Jaén, Sevilla and Córdoba).

\section{[Insert Figures 1 and 2]}

The analysis proceeds with the estimation of the convergence equation in order to detect to what extent the evolution of a region's efficiency level is determined by its initial level. The results are reported in Tables 4, 5 and 6.

[Insert Tables 4, 5 and 6]

Both one and two-step GMM estimators are applied since the later estimator allows the errors to be heteroscedastic. The Stata command for the two-steps GMM estimator includes the Windmeijer (2005) correction which 
makes the two-step GMM estimator more efficient in comparison with the firststep one, especially for the System-GMM (Roodman, 2006). The diagnostics confirm the validity of the instruments in both cases. The results obtained provide evidence of $\beta$-convergence as the $\beta$-coefficient is always negatively significant. Therefore, the regional growth effects are linked with efficiency improvements. And in particular, the lower the region's initial efficiency level, the higher its growth rate over the period.

The beneficial impact of human capital development as evidenced by the negative and significant association between the human capital proxies and regional inefficiencies, coupled with the evidence of $\beta$-convergence, suggests that the development of human capital positively aids in regional growth towards the best practice frontier.

\section{Conclusion}

Using the NUTS III level data set on Spanish regional growth, this paper applies the stochastic frontier analysis approach to assess the degree to which regional productivity growth is affected by human capital development. The application of this methodology leads to new findings on regional efficiency growth in Spain and has direct consequences in informing policies designed to enhance regional development. Unlike the approach typically adopted in regional growth studies, SFA accounts for instances where regional production can deviate from the maximum possible due to both technically inefficient production and random disturbances. The results provide evidence that the higher the level of human capital, the lower is the regional inefficiency. Comparing to the other education levels, secondary 
schooling has the strongest effect on the decline of regional inefficiency. As higher education is more important for innovation, while secondary education is more appropriate for the imitation activities (Ang et al., 2011), this result suggests that the composition of GDP is dominated by imitation sectors. Despite the regional disparities, there is evidence that the potential for technological improvement has been positively exploited by the least efficient regions which have been converging towards the best practices.

\section{References}

Afonso, A. and St. Aubyn, M. (2010), "Public and private inputs in aggregate production and growth: a cross-country efficiency approach," Working Paper Series, 1154, European Central Bank.

Aigner, D., Lovell C. and Schmidt, P. (1977), "Formulation and estimation of stochastic frontier production function models", Journal of Econometrics, Vol. 6 No.1, pp. 21-37.

Albert, M. (2000), "Efficiency and technical progress: sources of convergence in the Spanish regions", Applied Economics, Vol. 32 No.4, pp. 467-478.

Ang, J., Madsen, J. and Islam, M. (2011), "The effects of human capital composition on technological convergence", Journal of Macroeconomics, Vol. 33 No. 3, pp. $465-476$.

Badunenco, O. and Romero-Ávila, D. (2012), "Productivity Growth across Spanish Regions and Industries: A Production-Frontier Approach", Regional Studies, 1-21, iFirst Article, 21 August.

Barro, R. and Sala-i-Martin, X. (1992), "Convergence", Journal of Political Economy, Vol. 100 No. 2, pp. 223-251. 
Battese, G. and Coelli, T. (1995), "A model for technical inefficiency effects in stochastic frontier production function for panel data", Empirical Economics, Vol. 20, pp. 325-332.

Bos, J., Economidou, M., Koette, M. and Kolar, J. (2010), "Do all countries grow alike?", Journal of Development Economics, Vol. 91 No. 1, pp.113127.

Bronzini, R. and Piselli, P. (2009), "Determinants of long-run regional productivity with geographical spillovers: The role of R\&D, human capital and public infrastructure", Regional Science and Urban Economics, Vol. 39, pp. 187-199.

Coelli, T., Rao, D. and Battes, G. (1998), An Introduction to Efficiency and Productivity Analysis, Kluwer Academic Publishers. Boston/Dordrecht/London.

de la Fuente, A. (2002), "On the sources of convergence: a close look at the Spanish regions", European Economic Review, Vol. 46, pp. 569-599.

Di Liberto, A. (2007), "Convergence Clubs and the Role of Human Capital in Spanish Regional Growth" in Surinach, J. et al. (ed.), Knowledge Externalities, Innovation Clusters and Regional Development, Edward Elgar.

Doran, J. and Jordan, D. (2013) "Decomposing European NUTS2 regional inequality from 1980 to 2009: National and European policy implications", Journal of Economic Studies, Vol. 40 Iss: 1, pp.22 - 38. 
Enflo, K. and Hjerstrand, P. (2009), "Relative sources of European regional productivity convergence: A bootstrap frontier approach", Regional Studies, Vol. 43 No. 5, pp. 643-659.

Galindo-Martín, M. and Álvarez-Herranz, A. (2004), "Human Capital and Economic Growth in Spanish Regions", International Advances in Economic Research, Vol. 10 No. 4, pp. 257-264.

Hansen, P. and Knowles, S. (1998), "Human capital and returns to scale", Journal of Economic Studies, Vol. 25 Iss: 2, pp.118 - 123.

Henderson, D. and Russell, R. (2005), "Human capital convergence: a production frontier approach", International Economic Review, Vol. 46 No. 4, pp. $1167-1205$.

Kumbhakar S. and Lovell C. (2000), Stochastic Frontier Analysis, Cambridge University Press, U.K.

López-Bazo, E. and Moreno, R. (2007), "Regional heterogeneity in the private and social returns to human capital", Spatial Economic Analysis, Vol. 2 No. 1, pp. 23-44.

López-Bazo, E. and Moreno, R. (2008), "Does Human Capital Stimulate Investment in Physical Capital? Evidence from a cost system framework", Economic Modelling, Vol. 25, pp. 1295-1305.

Lucas, R. (1988), “On the Mechanics of Economic Development”, Journal of Monetary Economics, Vol. 22 Iss: 1, pp. 3-42.

Mamatzakis E., Staikouras C., and Koutsomanoli-Filippaki, A. (2008), "Bank efficiency in the new European Union member states: Is there convergence?", International Review of Financial Analysis, Vol. 17, pp. $1156-1172$. 
Manca F. (2012), "Human capital composition and economic growth", Regional Studies, Vol. 46 No. 10, pp. 1367-1388.

Mankiw, G., Romer, D. and Weil, D. (1992), “A Contribution to the Empirics of the Economic Growth", Quarterly Journal of Economics, Vol. 107 No. 2, pp. 407-437.

Mastromarco, C. and Ghosh, S. (2008), "Foreign Capital, Human Capital, and Efficiency: A Stochastic Frontier Analysis for Developing Countries," World Development, Vol. 37 No.2, pp. 489-502.

Meeusen, W. and Van Den Broeck J. (1977), "Efficiency Estimation from Cobb-Douglas Production Functions with Composed Error", International Economic Review, Vol. 18 No. 2, pp. 435-444.

Petrakis, P. and Stamatakis, D., (2002). "Growth and educational levels: a comparative analysis", Economics of Education Review, Vol. 21, pp. 513521.

Ramos, R., Suriñach, J. and Artís, M. (2010), "Human Capital Spillovers, Productivity and Regional Convergence in Spain", Papers in Regional Science, Vol. 89, pp. 435-446.

Romer, P. (1990), “Endogenous Technological Change”, Journal of Political Economy, Vol. 98 No. 5, pp. S71-S102.

Roodman, D. (2006), "How to do xtabond2: an Introduction to Difference GMM and System GMM in Stata", Center for Global Development Working Paper No. 103, Washington.

Sanromá, E. and Ramos, R. (2007), "Local human capital and productivity: an analysis for the Spanish regions, Regional Studies, Volume 41 No. 3, pp. 349-359. 
Weill, L. (2009), "Convergence in banking efficiency across European countries", Journal of International Financial Markets, Institutions and Money, Vol. 19 No. 5, pp. 818-833.

\section{Biographical Details}

Catarina Cardoso holds a PhD in Economics from Loughborough University (United Kingdom) and a MSc in European Economics and an Honours degree in Economics from the University of Coimbra (Portugal). She is currently a Lecturer in Economics at the University of Westminster (United Kingdom).

Geetha Ravishankar holds a PhD in Economics and a MSc in Banking and Finance from Loughborough University (United Kingdom). 
Figure 1: Efficiency scores Model 1 - 1991

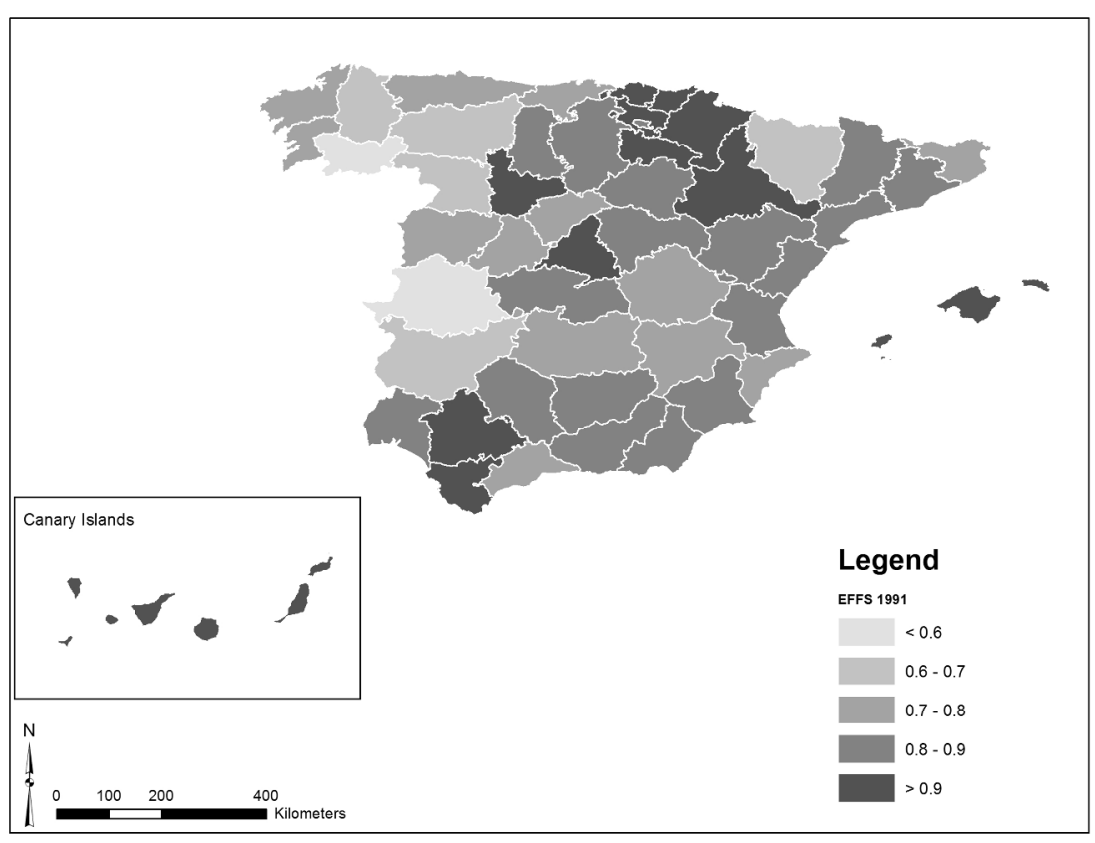

Figure 2: Efficiency scores Model 1 - 2006

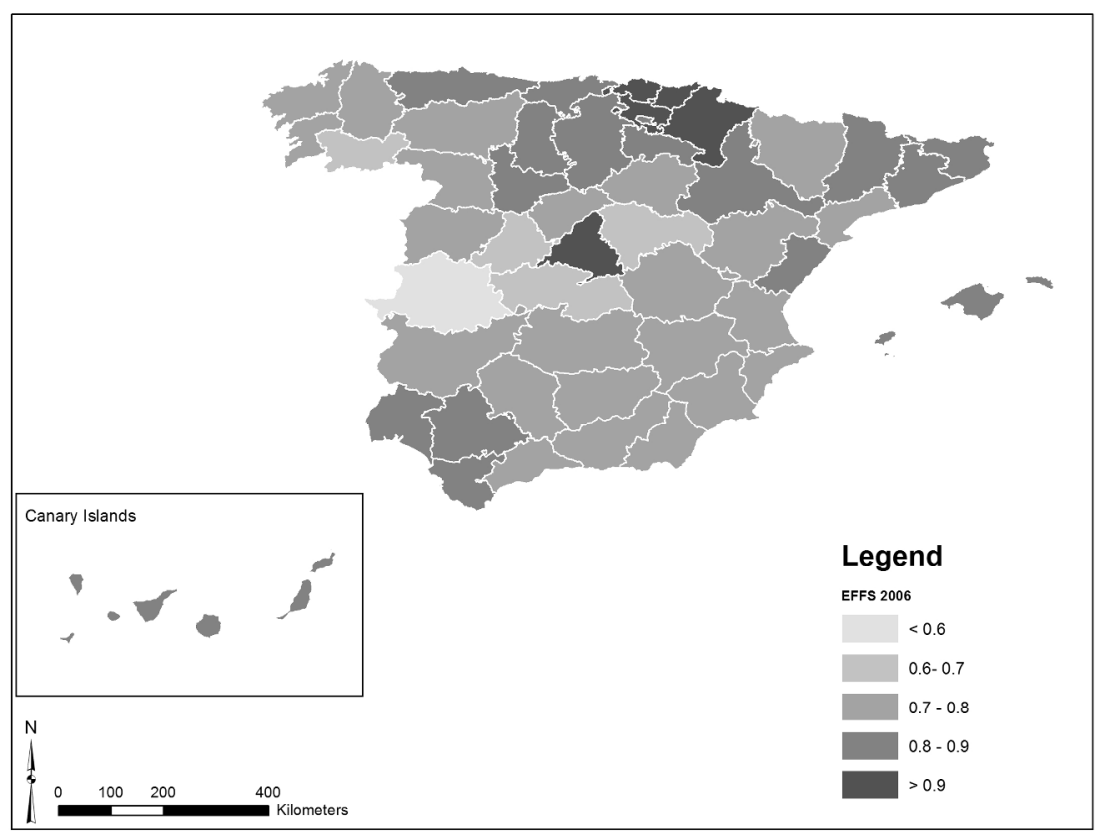


Table 1 - The richest and poorest regions in 1991

\begin{tabular}{|c|c|c|c|c|c|c|}
\hline \multirow{2}{*}{ Region } & \multicolumn{2}{|c|}{ GDP per worker } & \multirow{2}{*}{$\begin{array}{l}\text { Average } \\
\text { Education }\end{array}$} & \multicolumn{3}{|c|}{ Weight in total GVA } \\
\hline & Level & Growth rate & & Agriculture & Industry & Services \\
\hline \multicolumn{7}{|l|}{ The top 10 richest } \\
\hline Álava & 48.69 & 0.25 & 9.00 & 0.02 & 0.55 & 0.44 \\
\hline Madrid & 46.43 & -0.07 & 9.21 & 0.00 & 0.30 & 0.70 \\
\hline Tarragona & 45.41 & -0.60 & 7.92 & 0.03 & 0.59 & 0.38 \\
\hline Navarra & 45.35 & 0.08 & 8.84 & 0.05 & 0.47 & 0.48 \\
\hline Guadalajara & 44.81 & -1.97 & 8.14 & 0.07 & 0.56 & 0.38 \\
\hline Vizcaya & 43.74 & 0.59 & 9.42 & 0.02 & 0.49 & 0.48 \\
\hline Guipúzcoa & 42.65 & 0.84 & 8.89 & 0.02 & 0.47 & 0.51 \\
\hline La Rioja & 42.04 & -0.39 & 8.33 & 0.08 & 0.48 & 0.44 \\
\hline Baleares & 41.83 & -0.53 & 8.00 & 0.02 & 0.20 & 0.78 \\
\hline Las Palmas & 41.82 & -1.04 & 8.04 & 0.04 & 0.21 & 0.75 \\
\hline National average & 36.03 & 0.37 & 7.95 & 0.07 & 0.37 & 0.56 \\
\hline \multicolumn{7}{|l|}{ The 10 poorest } \\
\hline Avila & 31.35 & 0.69 & 7.60 & 0.10 & 0.25 & 0.65 \\
\hline Zamora & 30.05 & 1.70 & 7.72 & 0.11 & 0.28 & 0.61 \\
\hline León & 29.89 & 2.04 & 7.92 & 0.05 & 0.37 & 0.58 \\
\hline La Coruña & 29.57 & 0.97 & 7.53 & 0.06 & 0.43 & 0.51 \\
\hline Albacete & 28.99 & 0.67 & 7.46 & 0.10 & 0.30 & 0.60 \\
\hline Pontevedra & 27.52 & 1.36 & 7.52 & 0.13 & 0.35 & 0.52 \\
\hline Cáceres & 27.39 & 0.96 & 7.25 & 0.08 & 0.42 & 0.50 \\
\hline Badajoz & 27.29 & 1.11 & 7.57 & 0.12 & 0.25 & 0.63 \\
\hline Lugo & 25.37 & 2.18 & 7.03 & 0.12 & 0.33 & 0.55 \\
\hline
\end{tabular}


Table 2: Estimation Results using Battese and Coelli's (1995) SFA Model

\begin{tabular}{|c|c|c|c|}
\hline \multirow[b]{2}{*}{ VARIABLES } & \multicolumn{3}{|c|}{ GDP per worker } \\
\hline & Model1 & Model 2 & Model 3 \\
\hline \multirow[t]{2}{*}{ Capital per worker } & $0.386^{* * *}$ & $0.375^{* * *}$ & $0.314^{* * *}$ \\
\hline & $(0.0218)$ & $(0.0225)$ & $(0.0488)$ \\
\hline \multirow[t]{2}{*}{ Time } & 0.000003 & -0.00004 & -0.000002 \\
\hline & $(0.00002)$ & $(0.00003)$ & $(0.00002)$ \\
\hline \multirow[t]{2}{*}{ Capital per worker*Time } & & & $0.000183^{*}$ \\
\hline & & & $(0.000107)$ \\
\hline \multirow[t]{2}{*}{ Constant } & $0.208^{* * *}$ & $0.225^{\star * *}$ & $0.219^{* * *}$ \\
\hline & $(0.00900)$ & $(0.0146)$ & $(0.0127)$ \\
\hline \multicolumn{4}{|l|}{ Inefficiency Determinants } \\
\hline \multirow[t]{2}{*}{ Primary } & $-0.143^{* * *}$ & $-0.144^{* * *}$ & $-0.140^{* * *}$ \\
\hline & $(0.0220)$ & $(0.0220)$ & $(0.0213)$ \\
\hline \multirow[t]{2}{*}{ Secondary } & $-0.277^{* * *}$ & $-0.285^{* * *}$ & $-0.273^{* * *}$ \\
\hline & $(0.0466)$ & $(0.0472)$ & $(0.0450)$ \\
\hline \multirow[t]{2}{*}{ Tertiary } & $-0.105^{* * *}$ & $-0.105^{\star * *}$ & $-0.102^{* * *}$ \\
\hline & $(0.0207)$ & $(0.0209)$ & $(0.0200)$ \\
\hline \multirow[t]{2}{*}{ Agri. } & $0.621^{* * *}$ & $0.616^{* * *}$ & $0.648^{* * *}$ \\
\hline & $(0.0892)$ & $(0.0892)$ & $(0.0875)$ \\
\hline \multirow[t]{2}{*}{ Time } & 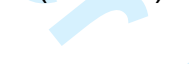 & $0.00007^{* *}$ & \\
\hline & & $(0.00004)$ & \\
\hline \multirow[t]{2}{*}{ Constant } & $0.743^{* * *}$ & $0.783^{* * *}$ & $0.741^{* * *}$ \\
\hline & $(0.0835)$ & $(0.0864)$ & $(0.0812)$ \\
\hline \multirow[t]{2}{*}{ Gamma $^{a}$} & $0.974^{* * *}$ & $0.973^{* * *}$ & $0.975^{\star * *}$ \\
\hline & $(0.014)$ & $(0.013)$ & $(0.017)$ \\
\hline Observations & 800 & 800 & 800 \\
\hline \multicolumn{4}{|c|}{$\begin{array}{l}\text { Notes: All the variables are measured in logs. Standard errors are reported in parentheses. } \\
\text { a Gamma, } \lambda=\sigma_{\mathrm{u}} / \sigma_{\mathrm{v}} \text {, ratio of the standard deviation of the inefficiency component to the standarc } \\
\text { deviation of the random error. } \\
{ }^{* * *},{ }^{* * *} \text { and }{ }^{* *} \text { indicate statistical significance at } 10 \%, 5 \% \text { level and } 1 \% \text { level. }\end{array}$} \\
\hline
\end{tabular}


Table 3: Average Regional Efficiency

\begin{tabular}{|c|c|c|c|c|c|c|c|c|c|c|c|}
\hline \multirow{2}{*}{ REGION } & Model 1 & $\begin{array}{c}\text { Model } \\
2\end{array}$ & Model 3 & \multirow{2}{*}{ REGION } & Model 1 & $\begin{array}{c}\text { Model } \\
2\end{array}$ & Model 3 & \multirow{2}{*}{ REGION } & \multirow{2}{*}{\multicolumn{2}{|c|}{$\begin{array}{c}\text { Model } \\
2 \\
\text { AVRE }\end{array}$}} & \multirow{2}{*}{$\frac{\text { Mode3 }}{\text { AVRE }}$} \\
\hline & $\mathrm{AVRE}^{1}$ & AVRE & AVRE & & AVRE & AVRE & AVRE & & & & \\
\hline Álava & 0.96 & 0.95 & 0.96 & Granada & 0.79 & 0.78 & 0.78 & Segovia & 0.79 & 0.8 & 0.78 \\
\hline Albacete & 0.76 & 0.74 & 0.73 & Guadalajara & 0.75 & 0.75 & 0.75 & Sevilla & 0.88 & 0.89 & 0.88 \\
\hline Alicante & 0.75 & 0.74 & 0.75 & Guipúzcoa & 0.94 & 0.94 & 0.93 & Soria & 0.78 & 0.79 & 0.77 \\
\hline Almería & 0.88 & 0.87 & 0.86 & Huelva & 0.84 & 0.83 & 0.83 & Tarragona & 0.85 & 0.87 & 0.83 \\
\hline Asturias & 0.8 & 0.79 & 0.79 & Huesca & 0.74 & 0.74 & 0.73 & Teruel & 0.85 & 0.86 & 0.83 \\
\hline Ávila & 0.72 & 0.72 & 0.72 & Jaén & 0.82 & 0.81 & 0.81 & Toledo & 0.75 & 0.76 & 0.75 \\
\hline Badajoz & 0.70 & 0.69 & 0.68 & La Coruña & 0.79 & 0.79 & 0.78 & Valencia & 0.81 & 0.82 & 0.81 \\
\hline Barcelona & 0.89 & 0.88 & 0.88 & La Rioja & 0.91 & 0.91 & 0.9 & Valladolid & 0.91 & 0.92 & 0.91 \\
\hline Burgos & 0.9 & 0.89 & 0.89 & León & 0.76 & 0.77 & 0.76 & Vizcaya & 0.95 & 0.96 & 0.94 \\
\hline Cáceres & 0.63 & 0.63 & 0.63 & Lleida & 0.90 & 0.90 & 0.89 & Zamora & 0.75 & 0.76 & 0.74 \\
\hline Cádiz & 0.90 & 0.89 & 0.89 & Lugo & 0.67 & 0.67 & 0.67 & Zaragoza & 0.89 & 0.91 & 0.89 \\
\hline Cantabria & 0.81 & 0.81 & 0.81 & Malaga & 0.77 & 0.77 & 0.76 & Baleares & 0.9 & 0.92 & 0.89 \\
\hline Castellón de la Plana & 0.86 & 0.86 & 0.86 & Murcia & 0.8 & 0.8 & 0.79 & Las Palmas & 0.88 & 0.9 & 0.88 \\
\hline Ciudad Real & 0.78 & 0.78 & 0.77 & Navarra & 0.97 & 0.97 & 0.96 & Santa Cruz de Tenerife & 0.76 & 0.78 & 0.75 \\
\hline Comunidad de Madrid & 0.96 & 0.96 & 0.96 & Orense & 0.65 & 0.65 & 0.65 & & & & \\
\hline Córdoba & 0.8 & 0.8 & 0.79 & Palencia & 0.83 & 0.84 & 0.82 & & & & \\
\hline Cuenca & 0.76 & 0.75 & 0.75 & Pontevedra & 0.75 & 0.75 & 0.75 & & & & \\
\hline Girona & 0.79 & 0.79 & 0.79 & Salamanca & 0.75 & 0.76 & 0.74 & & & & \\
\hline
\end{tabular}


Table 4 - System GMM results for the $\beta$-convergence equation

\begin{tabular}{lcc}
\hline \multicolumn{2}{l}{ Dependent Variable: Efficiency score from Model 1 } & \\
\hline & GMM 1 & GMM 2 \\
\hline$\alpha$ & $-0.05^{\prime \prime}(-2.48)$ & $-0.07^{\prime \prime \prime}(-2.72)$ \\
Eff ${ }_{i t-1}$ & $-0.19^{\prime \prime \prime}(-2.48)$ & $-0.28^{\prime \prime \prime}(-2.73)$ \\
No. Observations & 750 & 750 \\
No. Instruments & 30 & 30 \\
Arellano-Bond test for AR(2) & $-0.30(0.77)$ & $-0.35(0.73)$ \\
Sargan test & $18.38(0.19)$ & $18.38(0.19)$ \\
Hansen test & $14.85(0.39)$ & $14.85(0.39)$
\end{tabular}

Notes: t-statistics based on robust standard errors in brackets, except for the diagnostic tests which are the $p$-values. ${ }^{\star},{ }^{\star \star}$ and ${ }^{* \star \star}$ indicate statistical significance at $10 \%, 5 \%$ level and $1 \%$ level.

Table 5 - System GMM results for the $\beta$-convergence equation Dependent Variable: Efficiency score from Model 2

\begin{tabular}{lcc}
\hline & GMM 1 & GMM 2 \\
\hline$\alpha$ & $-0.05^{* *}(-2.58)$ & $-0.07^{* \cdots *}(-2.85)$ \\
Eff ${ }_{i t-1}$ & $-0.20^{* *}(-2.56)$ & $-0.28^{* * x}(-2.85)$ \\
No. Observations & 750 & 750 \\
No. Instruments & 30 & 30 \\
Arellano-Bond test for AR(2) & $-0.24(0.81)$ & $-0.29(0.78)$ \\
Sargan test & $17.75(0.22)$ & $17.75(0.22)$ \\
Hansen test & $13.95(0.45)$ & $13.95(0.45)$
\end{tabular}

Notes: t-statistics based on robust standard errors in brackets, except for the diagnostic tests which are the $p$-values. ${ }^{* * *}$ and ${ }^{* * *}$ indicate statistical significance at $10 \%, 5 \%$ level and $1 \%$ level. 
Table 6 - System GMM results for the $\beta$-convergence equation

\begin{tabular}{lcc}
\hline \multicolumn{2}{l}{ Dependent Variable: Efficiency score from Model 3 } & \\
\hline$\alpha$ & GMM 1 & GMM 2 \\
\hline Eff $_{\text {it }-1}$ & $-0.04^{\prime \prime \prime}(-2.43)$ & $-0.06^{\prime \prime}(-2.47)$ \\
No. Observations & $-0.18^{\prime \prime \prime}(-2.43)$ & $-0.25^{* \prime \prime}(-2.45)$ \\
No. Instruments & 750 & 750 \\
Arellano-Bond test for AR(2) & 30 & 30 \\
Sargan test & $-0.35(0.73)$ & $-0.39(-0.70)$ \\
Hansen test & $17.94(0.21)$ & $17.94(0.21)$ \\
\end{tabular}

Notes: t-statistics based on robust standard errors in brackets, except for the diagnostic tests which are the $p$-values. ${ }^{*},{ }^{* \star}$ and ${ }^{* * *}$ indicate statistical significance at $10 \%, 5 \%$ level and $1 \%$ level. 